\title{
RAPD Analysis Provides Insight into the Biology and Epidemiology of Uncinula necator
}

\author{
C. Délye, F. Laigret, and M.-F. Corio-Costet
}

First and third authors: Unité de Recherches Intégrées sur la Vigne, Institut National de la Recherche Agronomique, B.P.81, 33883 Villenave d'Ornon cédex, France; second author: Laboratoire de Biologie Cellulaire et Moléculaire, B.P.81, 33883 Villenave d'Ornon cédex, France.

Accepted for publication 25 March 1997.

\begin{abstract}
Délye, C., Laigret, F., and Corio-Costet, M.-F. 1997. RAPD analysis provides insight into the biology and epidemiology of Uncinula necator. Phytopathology 87:670-677.

Ninety isolates of grape powdery mildew (Uncinula necator) from Europe (sixty-two) and India (twenty-eight) were collected. Ten of the sixtytwo European isolates originated from mycelium overwintering in dormant buds ("flagshoots"). Mating types were determined, and genetic variation was assessed by random amplified polymorphic DNA (RAPD). Forty-one European isolates, including all "flagshoot" isolates, were

flagshoot isolates clustered in a second distinct group. These isolates, which coexisted with other isolates in the field, may represent a genetically isolated biotype of $U$. necator. Indian isolates clustered into two groups. The first group (15 isolates) was a subgroup of the group containing European nonflagshoot isolates. The second group (12 isolates) was distinct from the other groups. These two groups of Indian isolates may represent genetically isolated populations with different climatic tolerances. A polymerase chain reaction primer pair, derived from a RAPD fragment specific to the Indian isolates, proved to be suitable for field studies.
\end{abstract} mating type + , and twenty-one were mating type -. All Indian isolates were mating type -. Phenetic analysis based on 414 amplicons revealed three main groups. Most European isolates (53) clustered together. Nine
Additional keywords: cleistothecia, heterothallism, UPGMA, Vitis vinifera.
Powdery mildew, caused by the biotrophic ascomycete fungus Uncinula necator (Schwein.) Burrill, is one of the major diseases of grape (Vitis vinifera L.). This fungus is now present in vineyards throughout the world, but it is believed to originate from North America $(26,33)$. The first outbreak of $U$. necator in Europe occurred in England in 1845 and was related to increased trade with America. The fungus spread extremely rapidly: in only 7 years, grape powdery mildew caused heavy losses in vineyards throughout Europe and the Mediterranean Region (6,33). This spread was attributed to commercial exchange and/or wind dispersal $(6,33)$, although a recent study (36) has suggested that $U$. necator is incapable of being disseminated over long distances by wind.

Grape powdery mildew can overwinter as mycelium in dormant buds on leaf primordia $(5,23,25,37)$. The mycelium resumes activity at budbreak, causing the appearance of heavily infected sporulating shoots called "flagshoots," early in the growing season (5). U. necator is a heterothallic fungus $(16,28)$ that also can overwinter as cleistothecia (the ascigerous stage of this fungus) retained on the corky bark of grapevines $(7,13,22)$. In this case, the primary source of inoculum consists of ascospores released during spring $(11,14,15)$. In Europe, cleistothecia were not observed between 1845 and 1892 (8), suggesting that mycelium in dormant buds was possibly the only overwintering form of $U$. necator for more than 40 years. Currently, cleistothecia and/or flagshoots have been reported in vineyards throughout Europe; cleistothecia represent the most common way the fungus overwinters in Europe $(6,36)$.

Corresponding author: C. Délye; E-mail address: delye@bordeaux.inra.fr

Publication no. P-1997-0415-01R

(C) 1997 The American Phytopathological Society
Due to the obligate biotrophic nature of $U$. necator, little is known about its genotypic diversity, its epidemiology, or the importance of sexual reproduction. It is still unknown whether a given isolate is capable of overwintering both as cleistothecia and mycelium in buds or whether different biotypes of grape powdery mildew may exist. Because of the lack of epidemiological data concerning grape powdery mildew in Europe, no risk-assessment model has been developed for this disease. This has led to the use of systematic fungicide treatments, mainly with sterol biosynthesis-inhibiting compounds. As a consequence, development of resistance to these compounds was observed in field populations of $U$. necator in Portugal in 1988 (31). Resistance to these fungicides now has been detected in many European vineyards (30). A better knowledge of the biology and epidemiology of grape powdery mildew is required to develop integrated disease management strategies.

Epidemiological studies of $U$. necator require population or individual markers. Because there is no major resistance gene known in grape, no virulence/avirulence pattern can be established for characterization of $U$. necator populations. Recently, we developed a random polymorphic amplified DNA assay (RAPD [35]) suitable for genetic studies of grape powdery mildew (10). This technique has proved very useful for studying genetic variation in a number of fungal species $(9,17)$, including the biotrophic fungi that cause barley powdery mildew (19) and wheat leaf rust (18). RAPD markers are dominant (35), but the fact that $U$. necator is a haploid, uninucleate fungus greatly facilitates analyses. The purposes of the current study were (i) to obtain a large number of genetic markers suitable for epidemiological studies of grape powdery mildew in the vineyard and (ii) to determine whether significant genetic differences exist between isolates of $U$. necator overwintering in the asexual (mycelium) or sexual (cleistothecia) form. Insight into population biology is important, because genetic recombination occurring 
during sexual reproduction is likely to have consequences for the evolution of fungicide resistance in grape powdery mildew field populations.

\section{MATERIALS AND METHODS}

$\boldsymbol{U}$. necator isolates. The 90 isolates of $U$. necator used in this study are listed in Table 1. It was possible to collect European isolates only in vineyards where grape powdery mildew was not fully controlled by fungicide treatments. This resulted in an unbalanced sampling scheme. Except for "flagshoot" isolates, which were collected at the beginning of April, most European isolates were collected between May and September. To determine whether the same isolates of $U$. necator were capable of overwintering both in the dormant buds and as cleistothecia, FCP isolates were collected in the same vineyard and on the same grape plants on which both flagshoots and cleistothecia were present. Isolates FCP11 to -15 and FCP17 to -113 were collected immediately after the appearance of flagshoots (April) and 2 months after the ascospore release peak (August), respec- tively. Grape powdery mildew isolates from India were included in this study for the following reasons: (i) the outbreaks of $U$. necator in Europe and India seem to have occurred independently but in a similar way. Grape powdery mildew was reported in India in the early 1900s (32) and spread rapidly throughout the country. (ii) The environmental conditions in India are extremely different from those in Europe. In India, there is no dormancy, or only partial dormancy, of grape plants. Moreover, climatic variations between seasons and geographic areas are extremely wide. This may have influenced the evolution of $U$. necator populations. Indian isolates, therefore, were collected during the winter and summer in northern (Punjab) and southern India.

Isolates were taken from grape leaves, shoots, or green berries covered with sporulating powdery mildew. Young leaves from grape cv. Cinsaut were decontaminated by a 10 -min immersion in $50 \mathrm{~g}$ of calcium hypochlorite per liter, rinsed, and placed on agar medium at $20 \mathrm{~g} /$ liter. To obtain clonal isolates, a single powdery mildew conidium was picked from contaminated samples, using an eyelash fastened to a holder, under a binocular microscope under a laminar-flow hood. The conidium was placed on the upper

TABLE 1. Geographic origins of the 90 isolates of Uncinula necator used in this study

\begin{tabular}{|c|c|c|c|c|c|}
\hline \multirow[b]{2}{*}{ Isolates } & \multicolumn{2}{|c|}{ Geographic origin } & \multirow[b]{2}{*}{ Year of isolation $^{\mathrm{a}}$} & \multirow[b]{2}{*}{ Grape cultivar ${ }^{\mathrm{b}}$} & \multirow{2}{*}{$\begin{array}{l}\text { Mating } \\
\text { type }\end{array}$} \\
\hline & Country & Location & & & \\
\hline $\mathrm{FBO} 11^{\mathrm{c}},-12^{\mathrm{c}},-13^{\mathrm{c}}$ & France & Bordeaux & 1992 & Cabernet-Sauvignon & + \\
\hline FBO21 & France & Bordeaux & 1993 & Cabernet & + \\
\hline FBO31 & France & Bordeaux & 1994 & Cabernet & + \\
\hline FCP $11^{\mathrm{d}}-15^{\mathrm{d}}$ & France & Case de Pène & April 1994 & Carignan & + \\
\hline FCP18, $-19,-110$ & France & Case de Pène & 1994 & Carignan & + \\
\hline FCP16, -17, -111, -112, -113 & France & Case de Pène & 1994 & Carignan & - \\
\hline FIO11-14 & France & Île d'Oléron & 1994 & $\mathrm{SO} 4$ & + \\
\hline $\mathrm{FIO} 21^{\mathrm{c}, \mathrm{d}}$ & France & Île d'Oléron & April 1994 & Ugni blanc & + \\
\hline FMA1 $11^{\mathrm{c}}$ & France & Madiran & 1989 & Tannat & + \\
\hline FMA2 $1^{\mathrm{c}}$ & France & Madiran & 1990 & Tannat & + \\
\hline FMA31, -32 & France & Madiran & 1992 & Tannat & - \\
\hline FMA41 & France & Madiran & 1994 & Tannat & - \\
\hline FPE11 $1^{c},-12^{c}$ & France & Perpignan & 1993 & Carignan & - \\
\hline $\mathrm{FPE} 21^{\mathrm{c}},-31^{\mathrm{c}},-32$ & France & Perpignan & 1992 & Chardonnay & + \\
\hline FPE22 & France & Perpignan & 1992 & Chardonnay & - \\
\hline FPO $11^{c},-12^{c}$ & France & Poussan & 1993 & Carignan & - \\
\hline GNE11 $1^{\mathrm{d}},-12^{\mathrm{d}},-13^{\mathrm{d}},-14^{\mathrm{d}}$ & Germany & Neustadt & April 1994 & Kerner & + \\
\hline GUN11-14 & Germany & Ungstein & 1994 & Portugieser & - \\
\hline IBA 11,12 & India & Bangalore & 1995 & 29/7 hybrid & - \\
\hline IHY11-13 & India & Hyderabad & 1996 & Madhir Angow & - \\
\hline IHY21-24 & India & Hyderabad & 1996 & Perlette & - \\
\hline IJA11 & India & Jassian & 1994 & Perlette & - \\
\hline IJA21 & India & Jassian & 1995 & Perlette & - \\
\hline INA11 & India & Naruana & 1994 & Perlette & - \\
\hline IPA11-14 & India & P. A. U. ${ }^{\mathrm{e}}$ & 1994 & Perlette & - \\
\hline IPA21 & India & P. A. U. & 1995 & Perlette & - \\
\hline IPA31 & India & P. A. U. & 1996 & Perlette & - \\
\hline IPU11, -12 & India & Puna & 1995 & Thompson seedless & - \\
\hline IRA11, -12 & India & Rampura & 1995 & Perlette & - \\
\hline ISA11, $-12,-21,-22,-31,-32$ & India & Sangali & 1995 & Thompson seedless & - \\
\hline PAL11 ${ }^{\mathrm{c}}$ & Portugal & Alenquer & 1991 & Cardinal & + \\
\hline PAZ11 & Portugal & Azambuja & 1988 & Carignan & - \\
\hline PER11 $1^{\mathrm{c}}$ & Portugal & Ereira & 1991 & Carignan & + \\
\hline PPV11 ${ }^{\mathrm{c}}$ & Portugal & Portela do Vado & 1993 & Loureiro & + \\
\hline PTV $11^{\mathrm{c}},-12^{\mathrm{c}}$ & Portugal & Torres Vedras & 1993 & Carignan & + \\
\hline PTV $21^{\mathrm{c}}$ & Portugal & Torres Vedras & 1993 & Carignan & - \\
\hline PVA1 $11^{c},-12^{c},-21^{c},-22^{c}$ & Portugal & Varatojo & 1993 & Loureiro & + \\
\hline SLE11 & Switzerland & Leytron & 1994 & Gamay & + \\
\hline SNO11 & Switzerland & Noutze & 1994 & Gamay & + \\
\hline SNO21 & Switzerland & Noutze & 1994 & Gamay & - \\
\hline SSI1 $1^{\mathrm{c}},-12^{\mathrm{c}},-13^{\mathrm{c}}$ & Switzerland & Sion & 1993 & Chasselas & + \\
\hline $\mathrm{SSI} 21^{\mathrm{c}}$ & Switzerland & Sion & 1993 & Chasselas & - \\
\hline
\end{tabular}

a Unless mentioned, European isolates were collected between May and September.

b Cultivars from which the isolates were taken.

${ }^{c}$ Isolates used for preliminary random amplified polymorphic DNA amplifications with 95 primers.

d "Flagshoot" isolate.

e Punjab Agricultural University, Ludhiana, India. 
surface of a decontaminated leaf. After 14 days of incubation at $22^{\circ} \mathrm{C}$ under $16 \mathrm{~h}$ of illumination $(1,000 \mathrm{lux})$ per day, powdery mildew isolates were inoculated under sterile conditions onto the upper surface of four decontaminated grape leaves by blowing 600 to 800 conidia per $\mathrm{cm}^{2}$ of leaf with an air pump. They were allowed to grow for 14 days. The isolates were named with three letters and two numbers, indicating the country (first letter), the location in the country (second and third letters), the grape field (first number), and the sample (second number) from which each was isolated.

Mating studies. Isolates PTV11 (mating type +) and FPE11 (mating type -) were used as testers to determine the mating type of all other isolates. Isolates of unknown mating type were inoculated on four leaves together with tester isolate PTV11 or FPE11 and incubated at $22^{\circ} \mathrm{C}$ under $16 \mathrm{~h}$ of illumination (1,000 lux) per day for 14 days. The presence of cleistothecia was checked under the binocular microscope every 3 days for a period of 30 days. Sixty days after formation, the fertility of cleistothecia was assessed by squashing them in a drop of cotton blue on a microscope slide and checking for the presence of asci.

DNA extraction and RAPD amplifications. DNA from total fungal material (conidia plus mycelium) was extracted and amplified as previously described (10). Mycelium and conidia were harvested by scraping with a disposable scalpel 14-days after inoculation of leaves. Fungal material was subsequently freeze-dried. DNA was extracted by DNA-Now monophasic reagent (Biogentex, Seabrook, TX) and dissolved in sterile distilled water. DNA solutions were kept at $-20^{\circ} \mathrm{C}$. RAPD amplifications were performed in $20-\mu$ reaction mixtures containing $70 \mathrm{mM}$ Tris- $\mathrm{HCl}, 2 \mathrm{mM}$ $\mathrm{MgCl}_{2}, 17 \mathrm{mM}\left(\mathrm{NH}_{4}\right)_{2} \mathrm{SO}_{4}, 10 \mathrm{mM} \beta$-mercaptoethanol, $0.05 \%$ (wt/vol) polyoxyethylene-ether W1 (Sigma Chemicals, St. Louis), $0.2 \mathrm{mg}$ of bovine serum albumin per $\mathrm{ml}, 200 \mu \mathrm{M}$ each of dATP, $\mathrm{dCTP}$, dGTP, and dTTP, $0.4 \mu \mathrm{M}$ a single 10-mer oligonucleotide, $\sim 10$ ng of template DNA, and 0.2 units of Goldstar DNA polymerase (Eurogentec S.A., Seraing, Belgium). A Perkin-Elmer Cetus DNA thermal cycler (Perkin-Elmer Cetus Instruments Division, Norwalk, CT) was used with a program consisting of 37 cycles of $30 \mathrm{~s}$ at $94^{\circ} \mathrm{C}, 30 \mathrm{~s}$ at $37^{\circ} \mathrm{C}$, and $1 \mathrm{~min}$ at $72^{\circ} \mathrm{C}$. Ninetyfive-decamer primers (Operon Technologies, Alameda, CA) were used for the amplification of DNA from a first set of 26 isolates (Table 1). Primers that revealed polymorphism between

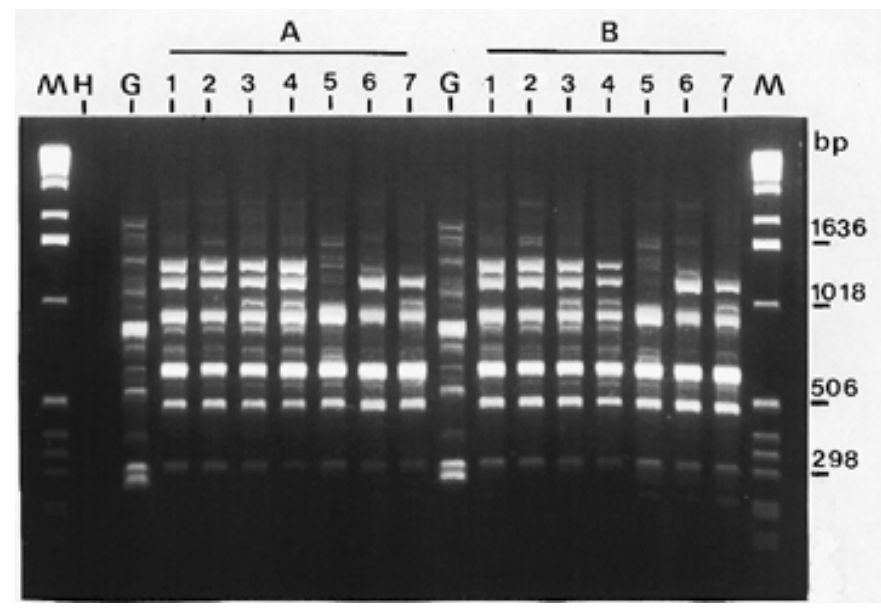

Fig. 1. Random amplified polymorphic DNA (RAPD) profiles of seven isolates of Uncinula necator obtained with primer OPE-7 (5'-AGATGCAGCC). RAPD patterns are shown for DNA extracted from asexual generation A, 1 and B, 36 of isolates IPA11 (lane 1), FBO11 (lane 2), SSI11 (lane 3), PTV11 (lane 4), INA11 (lane 5), GNE11 (lane 6), and FIO21 (lane 7). Lane G, amplification of DNA extracted from grape leaves following the same protocol used for fungal DNA extractions. Lane $\mathrm{H}, \mathrm{H}_{2} \mathrm{O}$ negative control (no DNA). Lane M, molecular weight marker (1-kb DNA ladder; Gibco-BRL, Gaithersburg, MD). these isolates were used subsequently to amplify DNA extracted from the remaining isolates (a list of primers that reveal polymorphism in $U$. necator is available from the authors upon request). At least two independent amplifications, using two different DNA samples, were performed for all isolate and primer combinations. The RAPD products were separated by electrophoresis at $110 \mathrm{~V}$ for $3 \mathrm{~h}$ on ethidium bromide-stained $(0.4 \mu \mathrm{g} / \mathrm{mm})$, $1.3 \%$ agarose gels run in $0.5 \times$ Tris-borate EDTA buffer and visualized under UV light.

Data analysis. Each isolate was scored for the presence or absence of each amplicon. When a primer revealed polymorphism, all detectable amplified DNA fragments were used for analysis and treated as binary characters. Genetic similarities were computed between all pairs of isolates using the formula given by Nei and $\operatorname{Li~(20):~} S=2 b_{i j} /\left(b_{i}+b_{j}\right)$, where $b_{i j}$ is the number of amplicons shared by two isolates, $i$ and $j$, and $b_{i}$ and $b_{j}$ are the total number of amplicons found in isolates $i$ and $j$, respectively. Genetic distances (or dissimilarities) were computed as genetic distance $=1-S$, and the data were used to construct a phenogram, using the unweighted pair-group method with arithmetic average (UPGMA [29]) or the Fitch-Margoliash method (12). Distance calculations and construction of a phenogram, using UPGMA, were performed using Splus 3.1 software (Statistical Sciences, Seattle). To check the robustness of the phenogram, the programs Kitsch and Drawgram contained in the PHYLIP software package (Phylogeny Inference Package, version 3.5.2, J. Felsenstein, University of Washington, Seattle) were used to construct a phenogram according to the Fitch-Margoliash method (12). A bootstrap analysis also was used to support major branches of the phenogram. One hundred bootstrap samples of the same size as the original RAPD data set were generated to compute one hundred genetic dissimilarity matrixes, using the Splus software. The programs Neighbor and Consense of the PHYLIP software package were used to construct the consensus UPGMA phenogram.

\section{RESULTS}

Mating studies. All isolates were paired with both tester strains and formed abundant cleistothecia within 14 to 18 days when paired with isolate PTV11 or FPE11. The isolates consequently were assigned $\mathrm{a}+$ or - mating type (Table 1 ). No isolate produced cleistothecia alone or with both tester isolates. All 10 flagshoot isolates were mating type + . Among the 52 remaining European isolates, 31 were mating type + , and 21 were mating type -. All 28 Indian isolates were mating type -.

RAPD amplifications. Of the 95 primers tested, 46 revealed polymorphism among a first set of 26 isolates (Table 1). These primers were retained for RAPD amplification of DNA extracted from the 64 remaining isolates to obtain as many polymorphic amplicons specific to one isolate or group of isolates as possible. Such amplicons are of interest for the development of molecular epidemiological tools, although primer selection leads to an overestimation of genetic dissimilarities computed between isolates of $U$. necator. All RAPD profiles, including amplicons of weak intensity, were fully reproducible for at least two independent assays using two independent DNA extractions. Furthermore, RAPD profiles were unchanged when DNA samples from the same isolates were prepared 18 months apart, which corresponded to 36 asexual generations (Fig. 1). No contamination by grape DNA was detected in RAPD amplifications, as was reported previously (10).

Data analysis. The $46 \mathrm{RAPD}$ primers tested on the $90 \mathrm{U}$. necator isolates yielded 414 amplicons (9.1 per primer), 216 (52.3\%) of which were polymorphic. The sizes of the amplified DNA fragments ranged from 0.2 to $3 \mathrm{~kb}$. All amplicons obtained were used to establish a matrix of genetic distances. The mean genetic dissimilarity obtained for the 90 isolates was 0.0955. UPGMA (Fig. 2) and Fitch-Margoliash (12) (data not shown) methods pro- 
duced very similar phenograms. In both cases, cluster analysis revealed three distinct groups (groups I, II, and III). Bootstrap analysis with 100 repetitions showed that these groups were present in $100 \%$ of the generated trees. With respect to the geographic origin of the isolates, group III was split into two subgroups (subgroups III-1 and III-2). These subgroups appeared as distinct groups in only $35 \%$ of the trees, but all isolates in subgroup III-1 clustered in a specific clade in $78 \%$ of the trees. Group I included 9 of the 10 European flagshoot isolates and the Indian isolate IBA11. Group I was clearly distinct from the other groups. The isolates in this group displayed 295 amplicons, 20 (6.8\%) of which were polymorphic. Isolate IBA11 differed from the other isolates in group I by 4 additional and 11 missing amplicons. Group II contained 12 closely related Indian isolates that displayed 290 amplicons, $13(4.5 \%)$ of which were polymorphic. Mean genetic dissimilarity between groups I and II was high (0.2041; Table 2) compared to the general mean genetic dissimilarity (0.0955). The two subgroups in group III were closely related, exhibiting a between-group genetic dissimilarity of 0.0374 (Table 2). Subgroup III- 2 contained 53 isolates, all from Europe. Isolates clustered in

\section{Genetic dissimilarity}

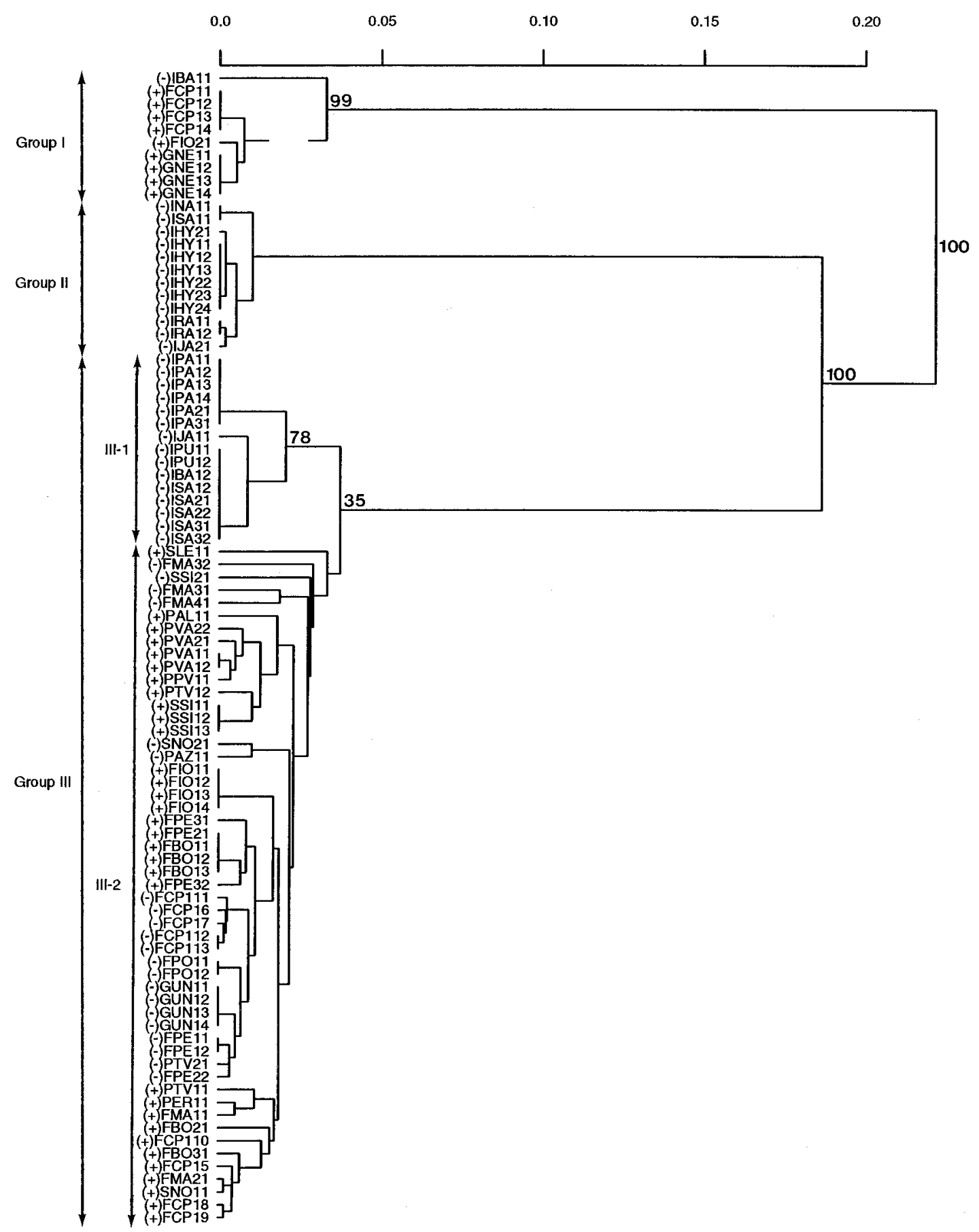

Fig. 2. Phenogram generated by unweighted pair-group method with arithmetic average cluster analysis of random amplified polymorphic DNA (RAPD) data from 90 isolates of Uncinula necator. Genetic dissimilarities were calculated using Splus software, based on 414 RAPD markers generated by 46 primers. The mating types of isolates are shown between brackets. Numbers at major nodes indicate the number of times the group of isolates to the left of the node occurred among a sample of 100 bootstrap-generated phenograms. 
subgroup III-2 displayed 337 amplicons, 75 (22.2\%) of which were polymorphic. Within this group, isolates from Switzerland, Portugal, and Madiran (France, FMA isolates) generally clustered in neighboring clades. The remaining French isolates clustered with the German isolates. Isolates originating from the same vineyard or vine-production area generally clustered together. Isolates in subgroup III-2 also had a tendency to cluster according to their mating type (Fig. 2). Subgroup III-1 contained the 15 remaining Indian isolates. They displayed 299 amplicons, 14 (4.7\%) of which were polymorphic.

Distribution of amplicons exclusively present or absent in the RAPD patterns of all isolates clustered in one or two groups was as follows. Isolates in group I shared 24 specific amplicons. They did not exhibit 17 of the amplicons present in all other isolates. Isolates in group II shared 27 specific amplicons and did not exhibit 11 of the amplicons present in all other isolates. All isolates in groups I and II shared seven amplicons that were absent in the remaining isolates. None of these isolates displayed 21 of the amplicons present in isolates in group III. One specific amplicon was displayed by all Indian isolates in group II and subgroup III-1, but not by Indian isolate IBA11, which clustered in group I. Two amplicons seemed to be related to mating type. They were displayed exclusively by all mating type + isolates. A total of 13 amplicons exclusively found in one isolate or one group of isolates with identical RAPD patterns were obtained. These "rare" amplicons are of interest for the development of molecular tools for epidemiological studies.

To determine whether polymerase chain reaction (PCR) primers derived from specific RAPD amplicons may be suitable for detection of particular isolates in the vineyard, the two extremities of the 1-kb RAPD fragment specific to Indian isolates were sequenced. The sequence characterized amplified region (SCAR)PCR (21) primers deduced from the sequence were SU12 (5' TCTGGAGCGCTGGTCTAG) and SU12R (5' TAGCCGCTCTCACTTTCTTC). PCR amplifications were performed with DNA extracted from the $90 \mathrm{U}$. necator isolates, grape, Plasmopara viticola (grape downy mildew), and various saprophytic fungi that grew on potato dextrose agar plates in which nondecontaminated grape leaves collected from the vineyard were placed. These fungi were mostly Botrytis sp., Trichoderma sp., Penicillium sp., Rhizopus nigricans, and unidentified yeasts. The same reaction mixture was used as was used for RAPD amplifications. PCR primers were used at a final concentration of $0.1 \mu \mathrm{M}$ each, and the annealing temperature was $60^{\circ} \mathrm{C}$. No amplification was obtained with DNA extracted from grape, downy mildew ( $P$. viticola) (data not shown), or other fungi (Fig. 3). All Indian isolates, except isolate IBA11, displayed the expected 1-kb PCR fragment. This fragment was not amplified from the remaining $U$. necator isolates. However, some of them (25 isolates, including isolate IBA11) exhibited an unexpected 1.5-kb PCR fragment when their DNA was subjected to PCR with primers SU12 and SU12R (Fig. 3).

To estimate the detection threshold of this assay, freeze-dried fungal material from Indian grape powdery mildew isolates and saprophytic fungi from the vineyard were mixed in $1 / 1,1 / 10,1 / 100$, $1 / 300,1 / 500,1 / 700$, and $1 / 1,000$ (wt/wt) proportions before DNA extraction and PCR amplification (Fig. 3). Amplifications were performed three times with three different DNA extractions. Ampli-

TABLE 2. Arithmetic mean genetic dissimilarities within and between the groups of isolates of Uncinula necator identified by phenetic analysis

\begin{tabular}{lcccc}
\hline & Group I & Group II & Subgroup III-1 & Subgroup III-2 \\
\hline Group I & 0.0089 & 0.2041 & 0.2293 & 0.2232 \\
Group II & & 0.0045 & 0.1856 & 0.1867 \\
Subgroup III-1 & & & 0.0106 & 0.0374 \\
Subgroup III-2 & & & & 0.0193 \\
\hline
\end{tabular}

fication of the 1-kb PCR fragment was obtained for all mixtures ranging from proportions of $1 / 1$ to $1 / 500$. Amplification of this fragment in $1 / 700$ proportion mixtures was not obtained in all assays. The lower limit for detection of an Indian isolate of $U$. necator, thus, was $1 \mathrm{mg}$ dry weight of powdery mildew for $500 \mathrm{mg}$ dry weight of other fungi.

\section{DISCUSSION}

Genetic dissimilarity among 90 clonal isolates of $U$. necator was evaluated using the RAPD technique. Phenetic analysis revealed three distinct groups of isolates of $U$. necator (Fig. 2). Group III was split into two subgroups: subgroup III-1 contained only Indian isolates, whereas subgroup III-2 contained only European isolates.

European isolates. The major subgroup in group III, subgroup III-2, included all of the European isolates, except 9 of the 10 flagshoot isolates. The low percentage of polymorphic amplicons found among isolates in this group (22.2\%) was consistent with our preliminary study, in which 13 European isolates (FPO11 and -12; FPE11, -12, and -21; SSI11, -12, and -13; PVA11, -12, -21, and -22; and PPV11) were studied using 16 primers (10). These primers yielded 119 amplicons, 21 (17.6\%) of which were polymorphic. As was found previously, most Portuguese and Swiss isolates clustered together. Isolates originating from Madiran (FMA isolates) also clustered with Swiss and Portuguese isolates. Isolates originating from the same grape field generally were found in the same clusters (isolates PVA21 and -22 or FCP16, -17, -111, -112 , and -113 , for instance) or displayed identical RAPD patterns (isolates SSI11 to -13 or FIO11 to -14 , for instance) and were probably of the same clonal line.

A previous study reported that conidia of $U$. necator require high wind speed and/or substantial leaf vibrations to be released (36). The relative agreement found between geographic origin and the genetic dissimilarities of isolates, as well as these epidemiological data suggests that the conidia of $U$. necator are not easily nor massively disseminated by wind. Thus, human activity, such as trade of contaminated grape plants, could be a major cause of inoculum dispersal.

European isolates clustered into two distinct groups (group I and subgroup III-2). Group I contained all flagshoot isolates, except isolate FCP15. Despite diverse geographic origins, isolates in group I displayed small between-isolate dissimilarities (Table 2). All flagshoot isolates collected in the same grape field displayed identical RAPD patterns and were probably of the same clonal line. All flagshoot isolates were mating type + , whereas European isolates in group III included 32 mating type + and 21 mating type isolates.

Isolate FCP15, which was collected during April, together with isolates FCP11 to -14 (group I), displayed RAPD patterns similar to isolates FCP17 to -113 (subgroup III-2, collected during August on the same plants from which isolates FCP11 to -15 were collected). Both flagshoots and cleistothecia were present on these plants. This suggests that isolate FCP15 probably originated from an ascospore that was released early. It is known that, although most ascospore discharge occurs from May to July in Europe (36), ascospores are released from budburst to bloom of grapevines (14).

All group I-type European isolates (isolates FCP11 to -14, GNE11 to -14, and FIO21) were collected during April (Table 1). Group I-type isolates were not found in samples collected from May to September throughout Europe. The absence of group Itype isolates in the second sampling, collected during summer, suggests that flagshoot isolates were no longer actively developing in the vineyards or that they represented a small proportion of the powdery mildew population. It is possible that flagshoot isolates survive inside buds until the next grape budbreak, when new bud contamination occurs. This is consistent with previous 
data suggesting that bud infection by $U$. necator flagshoot isolates occurs early in the season (23).

The high genetic dissimilarity found between flagshoot isolates and the remainder of European isolates (Table 2), as well as the number of amplicons exclusively present ( 33 amplicons) or absent (35 amplicons) in flagshoot isolates, may be due to selection in relation to the overwintering stage or the absence of genetic recombination, and thus of sexual reproduction, between these two populations. This may be caused either by the early disappearance of flagshoot isolates in the vineyard or by sexual incompatibility. The second hypothesis is strengthened by pairing experiments. Cleistothecia formed abundantly and matured when flagshoot isolates were paired with tester isolate FPE11. However, these cleistothecia were devoid of ascogenous content 70 days after formation. This seems to be a case of "delayed incompatibility," which agrees with previous findings suggesting that heterothallism in $U$. necator is rather complex (16). Flagshoot isolates may have started to lose their mating capacities, possibly because of their asexual method of overwintering. Two "overwintering" biotypes of $U$. necator, thus, may exist in Europe: the "flagshoot" biotype, overwintering inside dormant buds infected early in the grapegrowing season, and the "cleistothecium" biotype, overwintering as cleistothecia formed at the end of the grape-growing season. A more extensive study, conducted on large samplings of isolates collected during spring and summer in vineyards where cleistothecia and flagshoots are both present, is required before definitive conclusions can be drawn.

The presence of two biotypes of $U$. necator in Europe may be related to the historical pattern of cleistothecia production observed after the disease was introduced. For more than 40 years after the introduction of grape powdery mildew into Europe, no cleistothecia were reported in vineyards (6). After first being observed in 1892 (8), cleistothecia occasionally were observed late in the season $(1,4)$. During the early 1940 s, cleistothecia appeared in large numbers in several European vineyards $(2,3,27,34)$. Peyronel (24) proposed that these events were due to independent introductions of the two mating types into Europe 40 years apart. Gadoury and Pearson (16) argued that the transition between the sparse and abundant production of cleistothecia was the consequence of the introduction of isolates with "delayed compatibility," followed by the introduction of readily compatible isolates. However, the only isolates they reported as having delayed compatibility originated from $V$. labrusca and $V$. labruscana, not from $V$. vinifera. In addition, no delayed compatibility was observed among European isolates in our mating studies. Thus, we suggest that flagshoot isolates may have been introduced first into Europe. Thereafter, group III-type isolates, mainly of a single mating type, would have been introduced, causing occasional sexual reproduction of grape powdery mildew. The second mating type may have been introduced during the late 1930s, causing locally abundant production of cleistothecia. The fact that significant cleistothecia production did not occur across Europe is consistent with a shortrange natural dissemination of $U$. necator. A study of genotypic diversity of $U$. necator in North America would be useful to check the hypothesis of successive introductions of $U$. necator isolates from this origin.

Indian isolates. Indian isolates clustered in two groups (groups II and III), except isolate IBA11, which clustered with the European flagshoot isolates in group I. This particular isolate, which did not exhibit the Indian isolate-specific 1-kb PCR fragment but, instead, displayed the $1.5-\mathrm{kb}$ PCR fragment in common with isolates in group I, could be a flagshoot-biotype isolate. Should this be true, the existence of the mating type - in the flagshoot biotype would be proved. Pairings of isolate IBA11 with tester isolate PTV11 yielded sterile cleistothecia. Pairings of this isolate with European flagshoot isolates currently are being performed.

Indian isolates clustered in subgroup III-1 are closely related to subgroup III-2 European isolates, suggesting a common origin for these two populations. No geographic clustering was observed within subgroup III-1: isolates IBA12 and IPU11 and -12 were collected in vineyards more than $900 \mathrm{~km}$ apart and displayed identical RAPD patterns. Conversely, isolates IJA11 and IPA11 to -14 , which were collected in two locations only $30 \mathrm{~km}$ apart, displayed distinct RAPD patterns. The same was observed for isolates clustered in group II: isolates ISA11 and INA11, which displayed identical RAPD patterns, were collected in vineyards more than 1,500 km apart, whereas isolates INA11 and IRA11 and -12 were obtained from vineyards only $20 \mathrm{~km}$ apart. It is likely that human activity, rather than wind dispersal, was involved in long-range dispersal of $U$. necator inoculum, because no grape fields were present between the vineyards in northern and southern India, which were more than $1,500 \mathrm{~km}$ apart. Introduction of exogenous inoculum by human activity, thus, may be the reason identical isolates have been found in vineyards $1,500 \mathrm{~km}$ apart.

The occurrence of two very distinct groups of isolates in India (Table 2) may be related to environmental factors. In tropical southern India, there is no dormancy of grape plants. Receptive grape shoots, thus, are present all year round, and the fungus does not need an overwintering stage. In northern India, grape plants do not bear leaves from December to February. However, dormancy is never completely established, and shoots and leaves continue to develop during this period. Grape powdery mildew, thus, may overwinter either in buds or on shoots. The sole significant difference between the periods of collection of group II- and subgroup III-1-type isolates was climatic. Subgroup III-1 isolates all were collected during the cold season in tropical southern India (isolates ISA, IBA, and IPU) or during spring in northern India (isolates IJA11 and IPA). Group II isolates, except isolate ISA11, all were collected under high-temperature conditions during the hot monsoon season in southern India (isolates IHY) or during summer in northern India (isolates IJA21, INA11, and IRA). Subgroup III-1-type isolates, thus, may be better adapted to coldseason conditions, whereas development of group II-type isolates, which are still present during the cold season (isolate ISA11), may be favored by high temperatures.

Sexual reproduction seems to be rare in India. It was observed only occasionally in the northern portion of the country. Because all 28 Indian isolates studied were mating type -, it is possible that

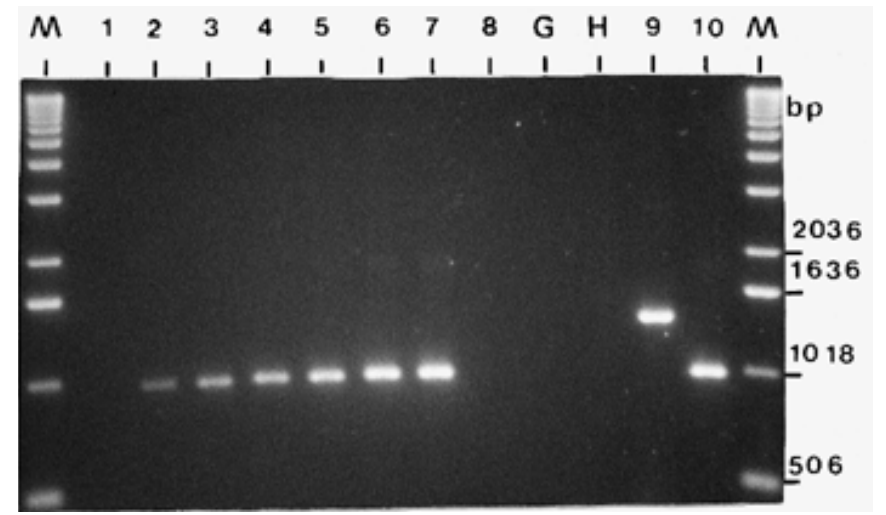

Fig. 3. Polymerase chain reaction (PCR) amplifications performed with primers SU12 and SU12R with DNA extracted from mixtures of fungal material obtained from Indian grape powdery mildew (Uncinula necator) isolate IPA11 and from saprophytic fungi from the vineyard (Botrytis sp., Trichoderma sp., Penicillium sp., Rhizopus nigricans, and unidentified yeasts) in $1 / 1,000,1 / 700,1 / 500,1 / 300,1 / 100,1 / 10$, and $1 / 1$ (wt/wt) proportions (lanes 1 to 7 , respectively). Lane 8, DNA extracted from fungi growing on potato dextrose agar plates. Lane $\mathrm{G}$, grape DNA. Lane $\mathrm{H}, \mathrm{H}_{2} \mathrm{O}$ negative control (no DNA). Lane 9, 1.5-kbp PCR fragment amplified from isolate FCP11. Lane 10, 1-kbp PCR fragment specific to Indian downy mildew isolates amplified from isolate ISA11. Lane M, molecular weight marker (1-kb DNA ladder; Gibco-BRL, Gaithersburg, MD). 
mating type + isolates may be absent from the southern and rare in the northern portions of the country. The alternate development of group II- and subgroup III-1-type isolates in Indian vineyards, as well as the rarity of mating type + isolates, may result in the genetic isolation of these two populations. It would be interesting to determine the temperature ranges and RAPD patterns of a large sample of Indian isolates collected at different periods in the same grape fields, because $U$. necator isolates with different climatic adaptation, to our knowledge, have never been described.

Conclusions. Data obtained from pairing experiments suggest that sexual incompatibility in $U$. necator may result either in the absence of formation of cleistothecia in pairing with one mating type (most isolates) or in the formation of sterile cleistothecia in pairing with the apparently compatible mating type (flagshoot isolates). Cloning and sequencing the two amplicons specific to mating type + isolates may lead to a better understanding of genetic control of sexual reproduction in $U$. necator.

The relative agreement found between geographic origin and genetic polymorphism of the European group III-type isolates of $U$. necator, as well as epidemiological data, suggests that human activity rather than wind transportation is responsible for the dissemination of grape powdery mildew. RAPD has proven useful in differentiating individual (clonal) grape powdery mildew isolates, and derived molecular tools, such as specific SCAR-PCR primers SU12 and SU12R, may be suitable for epidemiological field studies. Such molecular tools, thus, may be developed to assess the degree of gene flow between local $U$. necator populations. For this purpose, particular amplicons, such as amplicons specific to one isolate ("rare" amplicons) or to one population, are potentially of great interest. Using a range of SCAR primer pairs will make it possible to follow a "tagged" isolate and monitor its dispersal, survival, and the consequences of possible sexual reproduction with indigenous powdery mildew populations. Assessing the importance of sexual reproduction of $U$. necator in the field will provide a better understanding of the genetic control and evolution of the polygenic resistance of this fungus to sterol biosynthesis-inhibiting fungicides.

Amplicons particular to flagshoot isolates are also of great interest. Flagshoot isolates are very distinct genetically from other European isolates and may represent a particular, genetically isolated, biotype of $U$. necator. Should this be true, flagshoots and cleistothecia would have to be considered two independent sources of inoculum. Flagshoot-specific amplicons will facilitate development of molecular tools for gathering data concerning the biology of these isolates and monitoring powdery mildew population succession in the field. Molecular tools also may be used in the vineyard to gain a better understanding of the population genetics and epidemiology of $U$. necator. This, ultimately, will lead to more efficient disease control strategies for this important disease.

\section{ACKNOWLEDGMENTS}

We thank M. Dron and C. Neema (Institut de Biotechnologie des Plantes, Université Paris XI, France) for critical reading of the manuscript; K. Candresse and J.-P. Delbecque (CNRS, Bordeaux, France) for helpful corrections; H. Steva (Biorizon Company, Martillac, France) and T. Thind (Punjab Agricultural University, Ludhiana, India) for providing isolates of Uncinula necator; X. Capdevielle for technical assistance in maintaining U. necator isolates; and the Département de Phytopharmacie et Écotoxicologie de l'Institut National de la Recherche Agronomique for financial support.

\section{LITERATURE CITED}

1. Arnaud, G., and Arnaud, M. 1931. Traité de pathologie végétale. G. Arnaud and M. Arnaud, eds. T. L. P. Lechevalier, Paris.

2. Becker, H., and Schrodt, W. 1962. Zur Perithezienbildung des echten Mehltaues der Rebe (Uncinula necator (Schw.) Burr.) an verschiedenen
Unterlagenzürtungen. Weinberg Keller 9:69-76.

3. Bernard, A. C., and Mur, G. 1986. Présence des périthèces de l'Oïdium, en 1985, dans le midi. Prog. Agric. Vitic. 103:258-261.

4. Blumer, S. 1933. Die Erysiphaceen Mitteleuropas mit besonderer Berücksichtigung der Schweitz. Beitr. Kryptogamen Flora Schweitz. 7:483.

5. Boubals, D. 1961. Étude des causes de la résistance des Vitacées à l'Oïdium de la vigne (Uncinula necator (Schw.) Burr.) et de leur mode de transmission héréditaire. Ann. Amélior. Plant. 11:401-500.

6. Bulit, J., and Lafon, R. 1978. Powdery mildew of the vine. Pages 525548 in: The Powdery Mildews. D. M. Spencer, ed. Academic Press, London.

7. Cortesi, P., Gadoury, D. M., Seem, R. C., and Pearson, R. C. 1995. Distribution and retention of cleistothecia of Uncinula necator on the bark of grapevines. Plant Dis. 79:15-19.

8. Couderc, G. 1893. Sur les périthèces de l'Uncinula spiralis en France, l'identification de l'Oïdium américain et de l'Oïdium européen. C. R. Acad. Sci. Paris 116:210-211.

9. Crowhurst, R. N., Hawthorne, B. T., Rikkerink, E. H. A., and Templeton, M. D. 1991. Differentiation of Fusarium solani f. sp. cucurbitae races 1 and 2 by random amplification of polymorphic DNA. Curr. Genet. 20: 391-396.

10. Délye, C., Corio-Costet, M.-F., and Laigret, F. 1995. A RAPD assay for strain typing of the biotrophic grape powdery mildew fungus Uncinula necator using DNA extracted from the mycelium. Exp. Mycol. 19:234-237.

11. Diehl, H. J., and Heintz, C. 1987. Studies on the generative reproduction of grapevine powdery mildew (Uncinula necator Berk.). Vitis 26:114122.

12. Fitch, W. M., and Margoliash, E. 1967. Construction of phylogenetic trees. Science 155:279-284.

13. Gadoury, D. M., and Pearson, R. C. 1988. Initiation, development, dispersal and survival of cleistothecia of Uncinula necator in New York vineyards. Phytopathology 78:1413-1421.

14. Gadoury, D. M., and Pearson, R. C. 1990. Ascocarp dehiscence and ascospore discharge in Uncinula necator. Phytopathology 80:393401.

15. Gadoury, D. M., and Pearson, R. C. 1990. Germination of ascospores and infection of Vitis by Uncinula necator. Phytopathology 80:1198-1203.

16. Gadoury, D. M., and Pearson, R. C. 1991. Heterothallism and pathogenic specialization in Uncinula necator. Phytopathology 81:1287-1293.

17. Guthrie, P. A. I., Magill, C. W., Frederiksen, R. A., and Odvody, G. N. 1992. Random amplified polymorphic DNA markers: A system for identifying and differentiating isolates of Colletotrichum graminicola. Phytopathology 82:832-835.

18. Kolmer, J. A., Liu, J. Q., and Sies, M. 1995. Virulence and molecular polymorphism in Puccinia recondita f. sp. tritici in Canada. Phytopathology 85:276-285.

19. McDermott, J. M., Brändle, U., Dutly, F., Haemmerli, U. A., Keller, S., Müller, K. E., and Wolfe, M. S. 1994. Genetic variation in powdery mildew of barley: Development of RAPD, SCAR, and VNTR markers. Phytopathology 84:1316-1321.

20. Nei, M., and Li, W.-H. 1979. Mathematical model for studying genetic variation in terms of restriction endonucleases. Proc. Natl. Acad. Sci. USA 76:5269-5273.

21. Paran, I., and Michelmore, R. W. 1993. Development of reliable PCRbased markers linked to downy mildew resistance genes in lettuce. Theor. Appl. Genet. 85:985-993.

22. Pearson, R. C., and Gadoury, D. M. 1987. Cleistothecia, the source of primary inoculum for grape powdery mildew in New York. Phytopathology 77:1509-1514.

23. Pearson, R. C., and Gärtel, W. 1985. Occurrence of hyphae of Uncinula necator in buds of grapevine. Plant Dis. 69:149-151.

24. Peyronel, B. 1939. L'eterotallismo quale possibile causa della mancata o ritardata produzione della forma ascofora in talune Erysifaceae di origine esotica. Nuovo G. Bot. Ital. 2:316-319.

25. Sall, M. A., and Wrysinski, J. 1982. Perennation of powdery mildew in buds of grapevines. Plant Dis. 66:678-679.

26. Schweinitz, L. D. 1832. Synopsis fungorum in America boreali media degentium. Trans. Am. Phil. Soc. 4:270.

27. Seeliger, R. 1939. Beobachtungen das Auftreten der Perithezien des echten Mehltaues der Rebe. Arb. Biol. Reichsanst. Land. Fortwirtsch. 22: 453-478.

28. Smith, C. G. 1970. Production of powdery mildew cleistocarps in a controlled environment. Trans. Br. Mycol. Soc. 55:355-365.

29. Sokal, R. R., and Michener, C. D. 1958. A statistical method for evaluating systematic relationships. Univ. Kans. Sci. Bull. 28:14091438.

30. Steva, H. 1994. Evaluating anti-resistance strategies for control of Un- 
cinula necator. Pages 59-66 in: Fungicide Resistance, B. C. P. C. Monograph 60. S. Heaney, D. Slawson, D. W. Hollomon, M. Smith, P. E. Russels, and D. W. Parry, eds. The British Crop Protection Council, Farnham, England.

31. Steva, H., Cartolaro, P., Clerjeau, M., Lafon, R., and Gomes da Silva, M. T. 1988. Une résistance de l'Oïdium au Portugal? Phytoma 402:49-50.

32. Uppal, B. N., Cheema, G. S., and Kamat, M. N. 1931. Powdery mildew of the grape and its control in Bombay. Bombay Dep. Agric. Bull. 163:1-30.

33. Viala, P. 1885. L'Oïdium. Pages 67-124 in: Les maladies de la vigne. P. Viala, ed. B. Coulet, Montpellier, France.
34. Weltzien, H. C., and Weltzien, M. 1962. Cleistothecia von Uncinula necator in Würtemberg im 1961. Z. Pflanzenkrankh. 69:664-667.

35. Williams, J. G. K., Kubelik, A. R., Livak, K. J., Rafalski, J. A., and Tingey, S. V. 1990. DNA polymorphisms amplified by arbitrary primers are useful as genetic markers. Nucleic Acids Res. 18:6531-6535.

36. Willocquet, L. 1994. Influence des facteurs climatiques sur le développement épidémique de l'Oïdium de la vigne. Ph.D. thesis. Université Paris XI, Paris, France.

37. Yossifovitch, M. 1923. Contribution à l'étude de l'Oïdium de la vigne et son traitement. Ph.D. thesis. Université de Toulouse, Toulouse, France. 